\title{
Wind characteristics of CzeCOS's ecosystem station Bílý Kříž
}

\author{
*Vinh Xuan Nguyen ${ }^{1,2,3 *}$, Carlos P. Guerra Torres ${ }^{1,2,4}$, Shilpi Yadav ${ }^{1,2}$, Marian Pavelka ${ }^{1}$, \\ Marek V. Michal ${ }^{1}$
}

${ }^{1}$ Global Change Research Institute CAS, Bëlidla 986/4a, 60300 Brno, Czech Republic, email:nguyen.v@czechglobe.cz

${ }^{2}$ Faculty of Forestry and Wood Technology, Mendel University in Brno, Zemédèlská 1, 61300 Brno, Czech Republic

${ }^{3}$ Department of Ecology, Institute of Tropical Biology VAST, 85 Tran Quoc Toan Street, District 3, Ho Chi Minh City, Vietnam

${ }^{4}$ Department of Botany, University of Panama P.O.0824-00077 Panama, Panama

\author{
Abstract: Nguyen V.X., Guerra Torres C.P., Yadav S., Pavelka M., Marek M.V. 2017: Wind character- \\ istics of CzeCOS's ecosystem station Bílý Kř́̌́z - Beskydy, 10 (1, 2): 33-40
}

Eddy-covariance is a direct and accurate method to measure exchanges of greenhouse gases and energy between ecosystems and the atmosphere under good turbulent mixing conditions. Calm conditions can affect the accuracy of the eddy-covariance measurements by potential gas buildup below the measurement height. This study characterizes wind patterns and calm periods at Bílý Kř́íz Ecosystem Research Station, using four-year (20102013) wind data measured on an eddy-covariance tower at the site, located in Beskids Mountains, Czech Republic. The site is covered by young, dense Norway spruce forest on a $12.5^{\circ}$ slope facing South. The results show that the prevailing wind direction was from S to SW direction ( $55 \%$ frequency of occurrence), and to a much lesser extent from $\mathrm{N}, \mathrm{NE}$ and NW but including the strongest winds above $12 \mathrm{~m} \mathrm{~s}^{-1}$, possibly during gale or storm events. Calm condition $\left(\mathrm{u}<1 \mathrm{~m} \mathrm{~s}^{-1}\right)$ accounted for $34 \%$ of year time. Summer and Spring were the calmest seasons. Occurrence frequencies of calm conditions for the six-month periods from May to October (plant growing season) were higher than those for the remaining parts of the year (on average $39 \%$ vs $28 \%$ respectively). One should be aware of the calm periods in May-October when processing eddy-covariance data, since it is the time period of most contribution of forest ecosystem as a sink of $\mathrm{CO}_{2}$.

Keywords: Bílý Kř́ž, eddy-covariance, wind patterns, calm conditions

\section{Introduction}

The eddy covariance (EC) method is a micrometeorological technique for direct measurements of gas exchange between the surface and the atmosphere. It is widely used for quantifying $\mathrm{CO}_{2}$ emission rates from natural, urban and agricultural ecosystems, including areas of agricultural carbon sequestration (Burba et al., 2013). The method is based on turbulent transport across the plane of flux measurement and storage changes below the measurement plane. Under stable, low-wind conditions when turbulence is not well developed, often occurred at night, EC systems located above terrestrial ecosystems may report little or no $\mathrm{CO}_{2}$ exchange even when such exchanges are known to be occurring (Barr et al., 2013). 
Hence, understanding of the wind patterns and stability conditions of surface layer is needed in EC method. Flux data at very stable conditions may need to be corrected or discarded due to insufficient fetch of the ecosystem (Burba, 2013).

This study characterizes wind patterns and low-wind conditions at the Bílý Krríž Ecosystem Research Station, using horizontal wind speed data from the processed eddy-covariance data of four years (2010-2013) of the station.

\section{Materials and Methods}

The study site is located in Beskids Mountains of the Czech Republic near a mountain ridge, covered by young, dense Norway spruce (Picea abies [L.] Karst.) forest stand (planted in 1981, mean height of $13.9 \mathrm{~m}$ and stand density of 1,488 trees $\mathrm{ha}^{-1}$ at the end of the growing season of 2010) on a $12.5^{\circ}$ slope facing SSW (Sedlák et al., 2010, Marková et al., 2013).

Four-year data sets (2010-2013), measured by 3D sonic anemometer R3-100 until November 2011 and then by HS-50 (Gill, UK) as a part of the EC system placed on a meteorological tower at Bílý Kř́ž site $\left(49.5021^{\circ} \mathrm{N}, 18.5368^{\circ} \mathrm{E}, 875 \mathrm{~m}\right.$ a.s.l.) at the height of $18 \mathrm{~m}$ until October 2013 and $20.5 \mathrm{~m}$ afterwards, measured in $20 \mathrm{~Hz}$ and processed in form of half-hour records, were used to analyze the site's wind patterns. From 3-5\% records of yearly wind speed data were blank and removed from analysis. It is noted that there was a gap in wind data set of 2012, from January $21^{\text {st }}$ to February $21^{\text {nd }}$.

Calm periods were defined by horizontal wind speed $(\mathrm{u})$ less than $1 \mathrm{~m} \mathrm{~s}^{-1}$, where turbulence is not well-developed (Burba, 2013). Periods with calm conditions were assessed in relation with their associated wind directions, day-time vs. night-time, monthly and seasonally. Horizontal airflow was divided into eight wind direction sectors: North (N) from 0-23 and 338-360, North-East (NE) 23-68, East (E) 68-113, South-East (SE) 113-158, South (S) 158-203, South-West (SW) 203-248, West (W) 248-293, and North-West (NW) 293-338 degrees.

Day-time is defined from 0600 to 1800 and night-time is from 1800 to 0600 next day. Comparison was made between November-April and May-October, where the later falls in the main growing season of plants in temperate areas of the northern hemisphere (Hájková et al., 2012). This study also used meteorological seasons, which are reckoned by temperature, with summer being the hottest quarter of the year and winter the coldest quarter of the year. For temperate areas in the Northern hemisphere, spring begins on the $1^{\text {st }}$ of March, summer on the $1^{\text {st }}$ of June, autumn on the $1^{\text {st }}$ of September, and winter on the $1^{\text {st }}$ of December (New World Encyclopedia, 2015). The data were analyzed using MS Excel.

\section{Results}

\section{Wind characteristics}

Wind direction: Figs. 1 and 2 showed a uniform pattern in wind roses from each year, in particular prevailing wind came upslope from S (38\% frequency of occurrence observed in the four year dataset). Other minor dominant wind directions were from SW (17\%) going upslope; and from the North (15\%), NW (8\%) and NW (8\%) blowing over the ridge and then downslope on the lee side. Wind roses constructed for each month of year 2010 in Fig. 3 also revealed the site was under influence of prevailing winds from $\mathrm{S}$ and SW throughout the year, and markedly during October to December.

Wind intensity: On average of four-year data (2010-2013), calm periods were recorded $34 \%$ time of year (Tab. 1). Most strong winds (with speeds from 6-10 $\mathrm{m} \mathrm{s}^{-1}$ ) came from S and SW (Fig. 2). However, the strongest wind records (12-18 $\mathrm{m} \mathrm{s}^{-1}$, very strong wind, in Beaufort wind scale ranked from strong breeze to near gale and gale) observed in 2012 and 2013 came from N and NE, possibly during short storm or whirlwind events lasting from few hours to a couple of days in winter (November to early February). The maximum wind speeds observed from the datasets of half-hour records (i.e. already flatten out by averaging) was $18.9 \mathrm{~m} \mathrm{~s}^{-1}$ from NE in January 2013.

Monthly wind roses of 2010 in Fig. 3 showed that there was a period of continuous six months with moderate (4-6 $\left.\mathrm{m} \mathrm{s}^{-1}\right)$ to strong winds (characterized by significant occurrence of periods with wind speeds of 6-8 $\mathrm{m} \mathrm{s}^{-1}$ and some periods with wind speeds of $8-10 \mathrm{~m} \mathrm{~s}^{-1}$ ) from October to March. Other months were considered as with low wind conditions, especially from April to July (August for years 2013 and 2012) seemed to be the "calmest" months. 


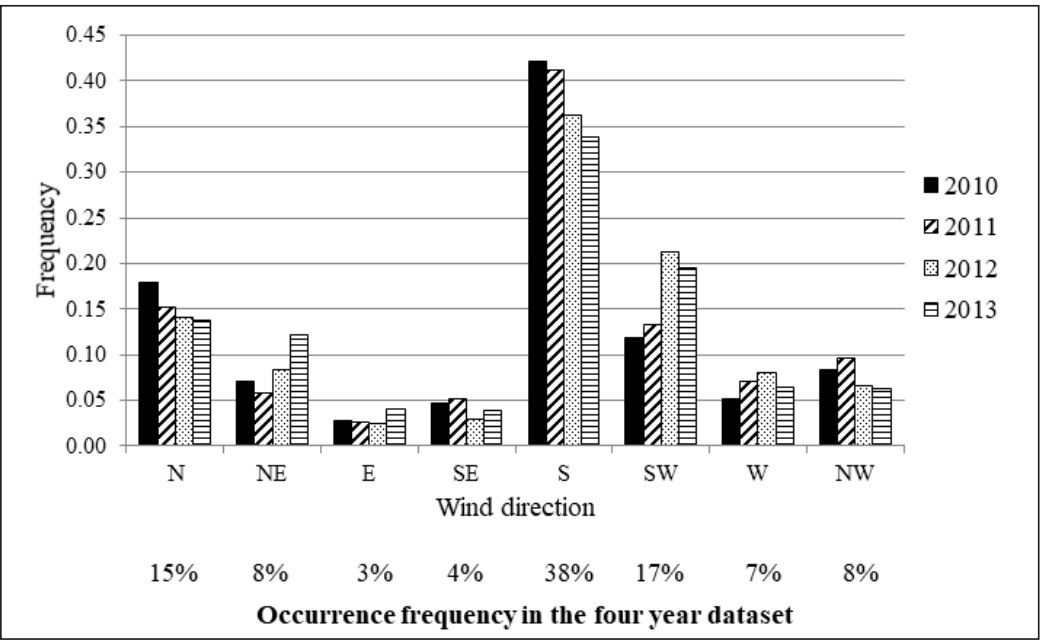

Fig. 1: Yearly wind direction frequency at Bílý Kř́ž Ecosystem Research Station during 2010-2013

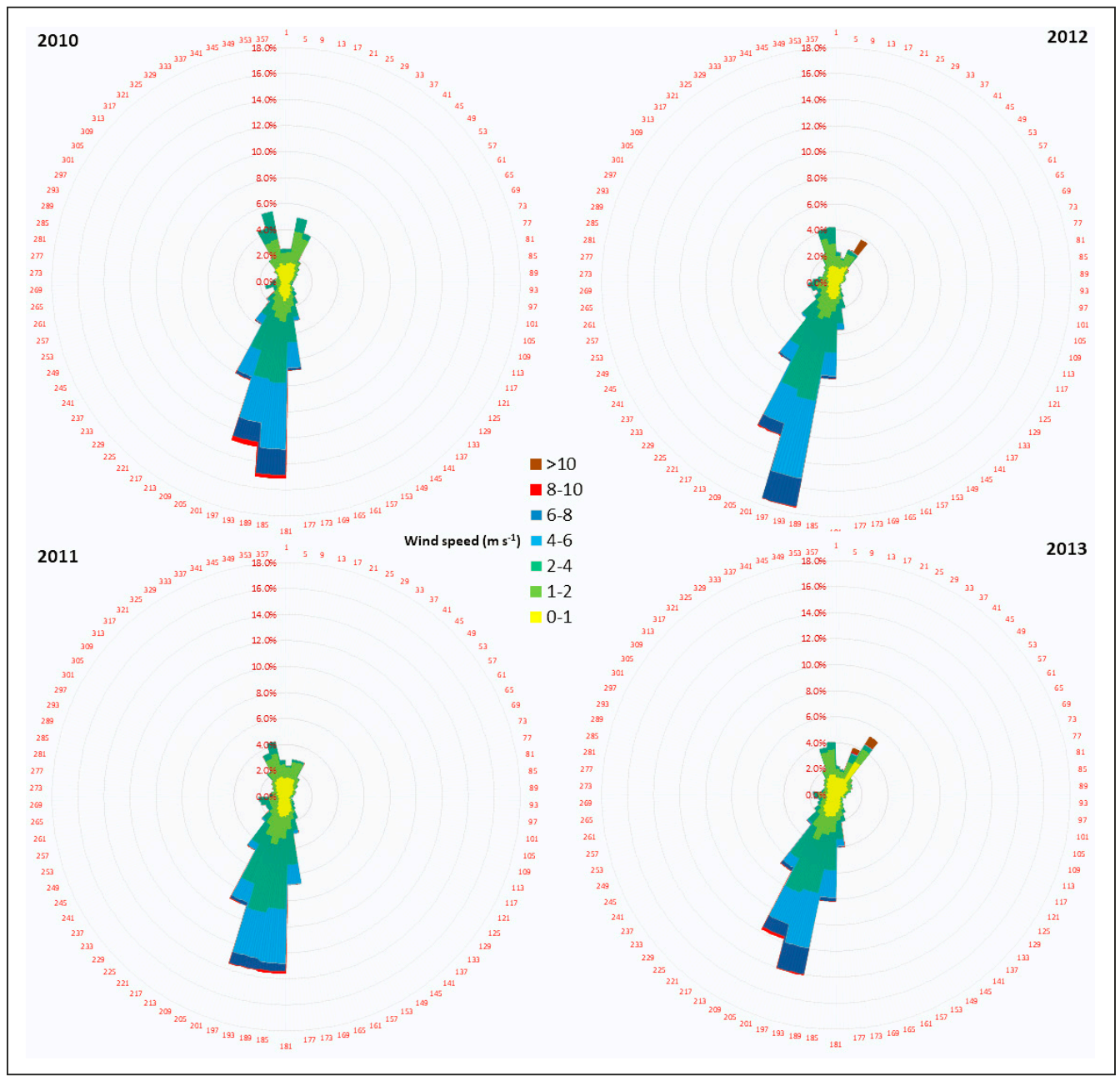

Fig. 2: Yearly wind roses at Bílý Kř́̌ Ecosystem Research Station during 2010-2013 


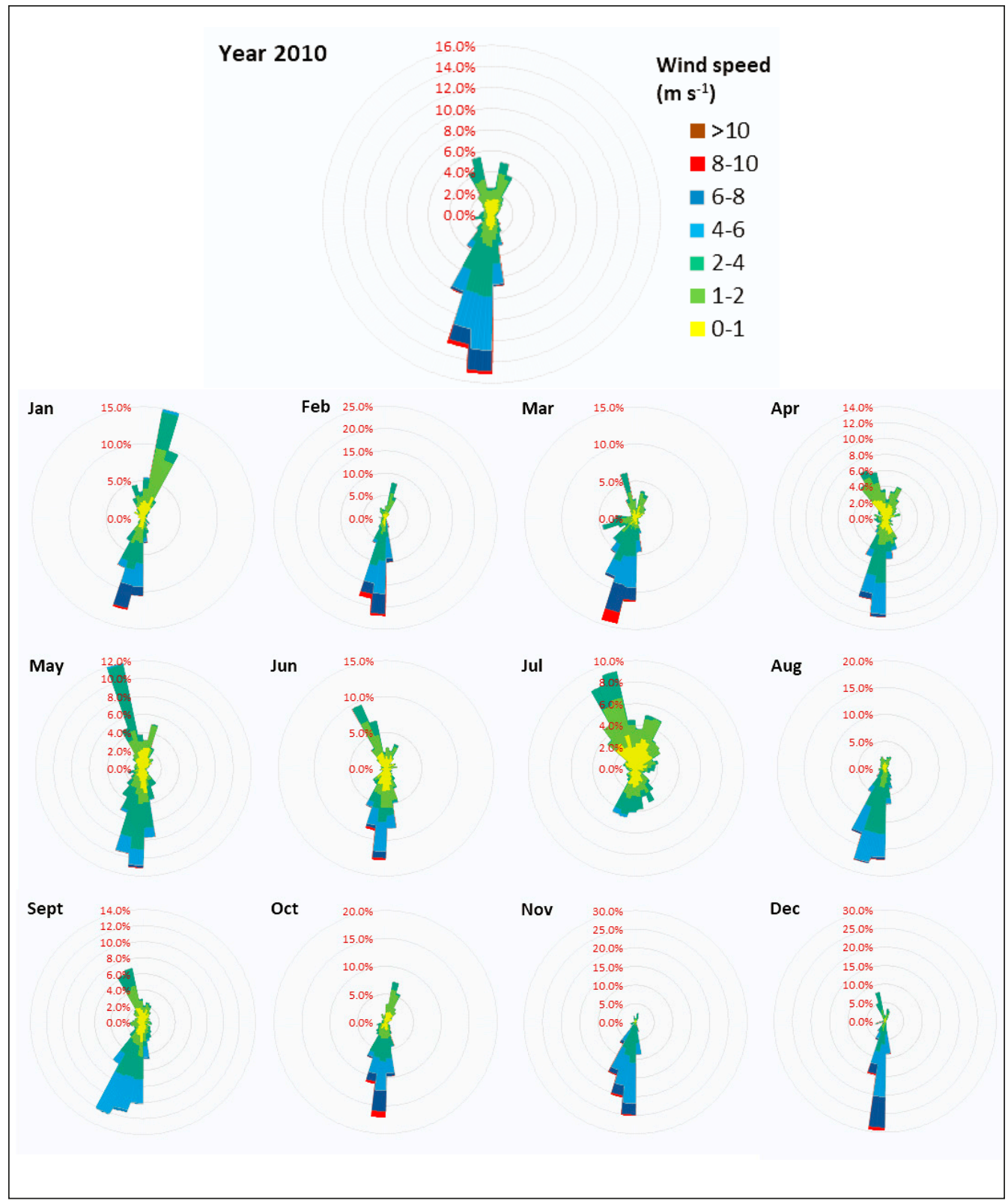

(Jan: January, Feb: February, Mar: March, Apr: April, May: May, Jun: June, Jul: July, Aug: August, Sept: September, Nov: November, Dec: December)

Fig. 3: Bily Kríž wind roses of the whole year and each month of 2010 


\section{Seasonal patterns}

From a closer look at meteorological seasons of four years, on average the highest frequency of calm periods occurred in summer (i.e. $11.4 \%$ of whole year), spring ranked second $(9.7 \%$ of whole year) and winter was the least (Tab. 2 and Fig. 4).

For all study years, occurrence frequencies of calm records in six-month period of May-October (coincident with main growing season of plants in temperate climate region) were much higher compared against November-April period, specifically $39 \%$ vs $28 \%$ for respective periods (Tab. 1 and Fig. 5), or $21 \%$ vs $13 \%$ respectively of whole year.

\section{Diurnal pattern}

Similar values of calm periods were obtained when compared night-time vs day-time during May-October period (40\% of night-time vs $39 \%$ of day-time) (Tab. 1). The difference was larger for November-April period, $30 \%$ vs $26 \%$ respectively.

Tab. 1: Calm conditions $\left(u<1 \mathrm{~ms}^{-1}\right)$ in different periods at Bílý Kř́z

\begin{tabular}{r|c|c|c|c|c}
\hline \multicolumn{1}{c|}{ Year } & $\mathbf{2 0 1 0}$ & $\mathbf{2 0 1 1}$ & $\mathbf{2 0 1 2}$ & $\mathbf{2 0 1 3}$ & Average \\
\hline Whole year & $\mathbf{3 1}$ & $\mathbf{3 4}$ & $\mathbf{3 2}$ & $\mathbf{4 0}$ & $\mathbf{3 4}$ \\
\hline Day-time & 30 & 33 & 30 & 39 & 33 \\
Night-time & 31 & $\mathbf{3 5}$ & $\mathbf{3 4}$ & 41 & $\mathbf{3 5}$ \\
\hline May-October & $\mathbf{3 7}$ & $\mathbf{3 8}$ & $\mathbf{3 7}$ & $\mathbf{4 6}$ & $\mathbf{3 9}$ \\
\hline Day-time & 38 & 37 & 35 & 44 & 39 \\
Night-time & 37 & 39 & 38 & 47 & 40 \\
\hline November-April & $\mathbf{2 3}$ & $\mathbf{3 0}$ & $\mathbf{2 6}$ & $\mathbf{3 4}$ & $\mathbf{2 8}$ \\
\hline Day-time & 21 & 28 & 24 & 33 & 26 \\
Night-time & 26 & 31 & 28 & 34 & 30 \\
\hline
\end{tabular}

(All values are percent of the time during a particular period)

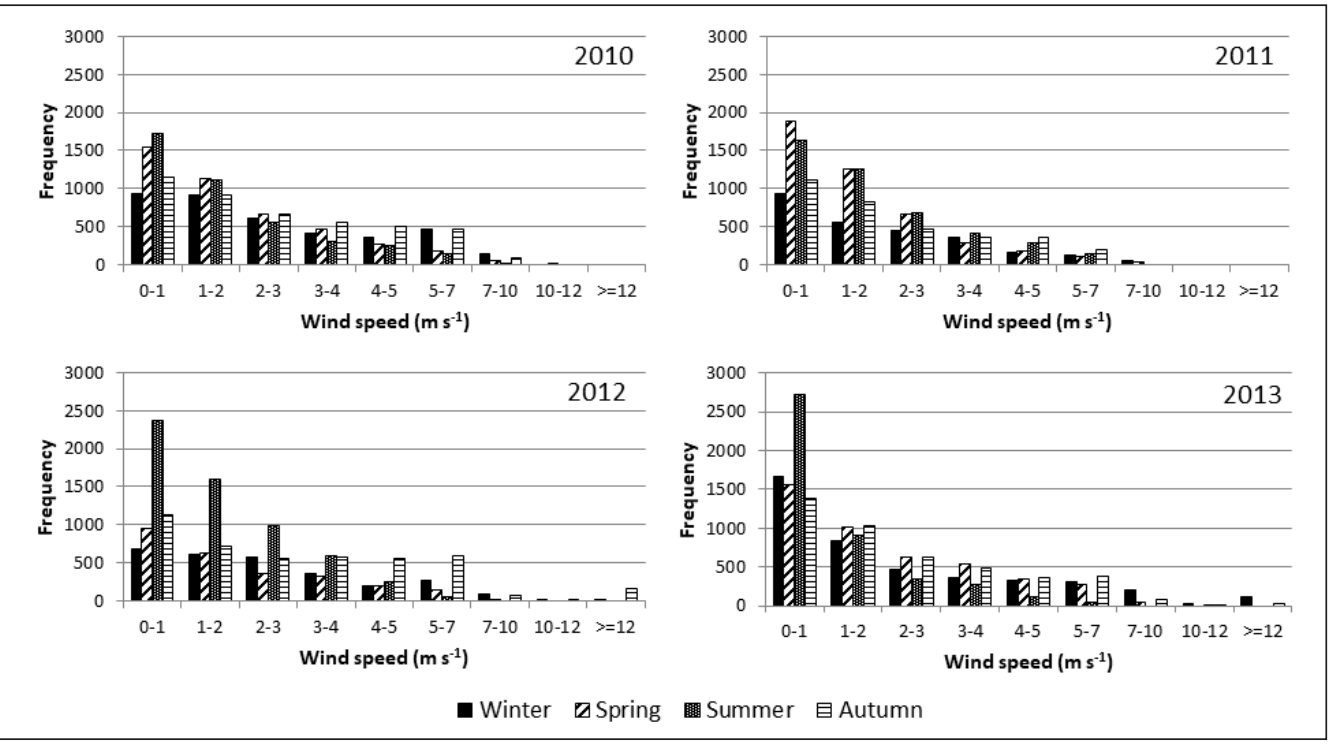

Fig. 4: Yearly wind speed frequency of occurrence for four meteorological seasons at Bílý Kř́ž 
Tab. 2: Occurrence frequency of calm periods $\left(u<1 \mathrm{~m} \mathrm{~s}^{-1}\right)$ compared among four seasons

\begin{tabular}{c|c|c|c|c}
\hline Year & $\begin{array}{c}\text { Winter } \\
\text { (Dec-Feb) }\end{array}$ & $\begin{array}{c}\text { Spring } \\
\text { (Mar-May) }\end{array}$ & $\begin{array}{c}\text { Summer } \\
\text { (Jun-Aug) }\end{array}$ & $\begin{array}{c}\text { Autumn } \\
\text { (Sept-Nov) }\end{array}$ \\
\hline 2010 & 5.4 & 8.9 & 9.8 & 6.5 \\
2011 & 6.0 & 10.8 & 9.3 & 7.7 \\
2012 & 3.9 & 10.3 & 10.4 & 7.2 \\
2013 & 7.4 & 8.9 & 15.9 & 7.8 \\
\hline Average & $\mathbf{5 . 7}$ & $\mathbf{9 . 7}$ & $\mathbf{1 1 . 4}$ & $\mathbf{7 . 3}$ \\
\hline
\end{tabular}

(All values are percentage of whole year)

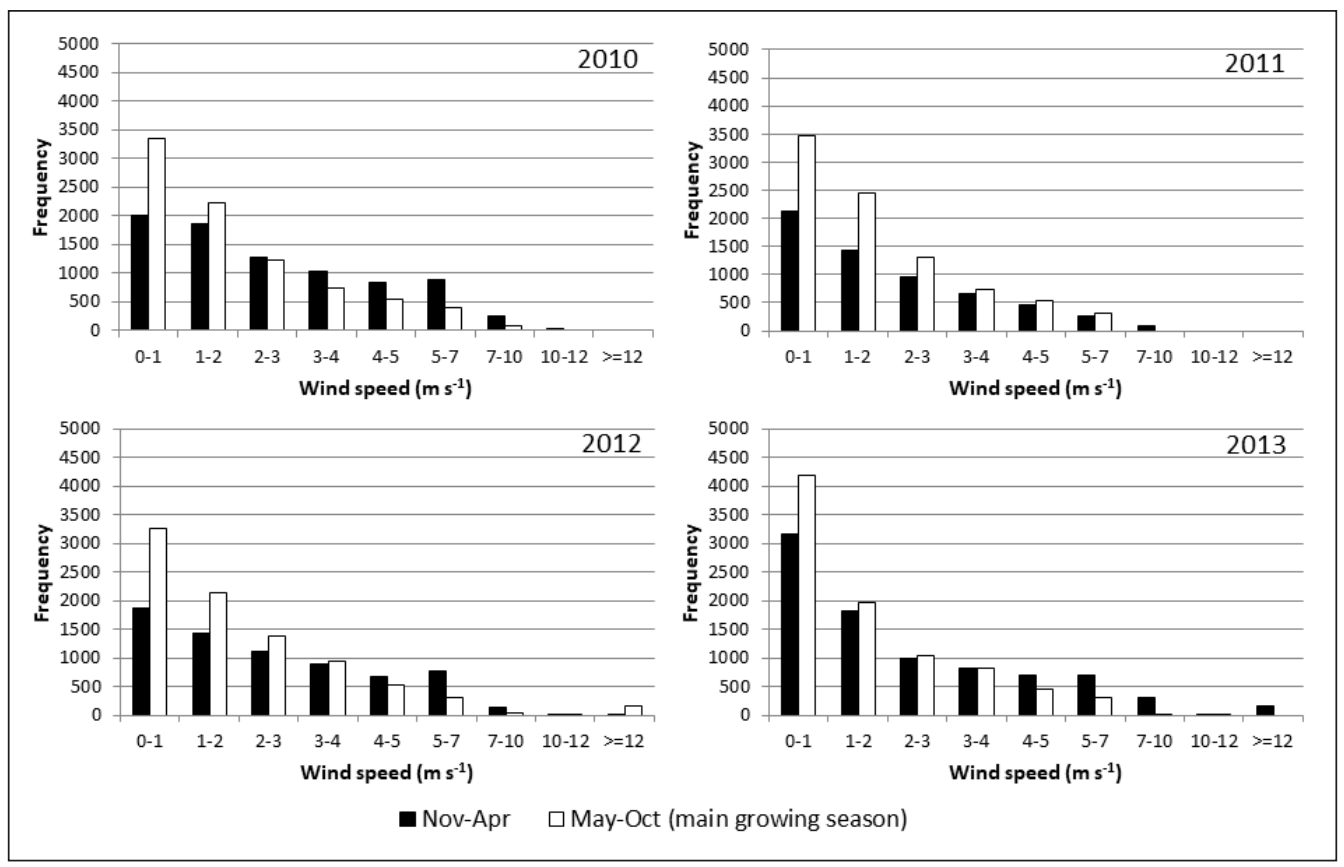

Fig. 5: Yearly wind speed frequency of occurrence for two six-month periods at Bíly Kř́ž

\section{Discussion}

Despite similarity of yearly wind patterns in Fig. 2, there was evidence of 10-degree angular rotation in wind roses of years 2010 and 2011, compared to those of years 2012 and 2013. At the end of 2011, sonic anemometer on the EC flux tower was changed. The replacement and new installation may have introduced a small difference in North spar registration between the old and new anemometers. It should be noted that the rotation angle was also limited by size of wind sector unit of 10 degree selected to create the wind roses. The difference between North spar orientations of the old and new anemometers is likely at the order of sub-degree or to a few degrees.
The topography of the Beskids Mountain range is quite complex. To certain extent, the prevailing winds above the site forest canopy coming from S, SW and N are shaped by local terrain. Havrankova and Sedlák (2004) reported that the flow at Bílý Kříž is strongly influenced by the surrounding terrain; and main features are the pronounced south-north flow channeling and local circulation patterns such as the mountain breeze. Findings from this study confirms the correct orientation of anemometer and gas analyzer on the EC flux tower, to the west of the tower.

In Bílý Kříž, summer was the calmest season (except in 2011) and winter was the least 
calm season. This observation agrees with general patterns of atmospheric circulation in the mid-latitude region (area between $30^{\circ}$ and $60^{\circ}$ latitude). Mid-latitude surface winds are primarily westerly and their strength is largely determined by polar votex, which strengthens in the winter and weakens in the summer due to its dependence on the temperature difference between the equator and the poles (Frauenfeld and Davis 2003, Randall, 2015).

The EC method often underestimates fluxes under stable, low-wind conditions at night when turbulence is not well developed (Barr et al., 2013). Under calm conditions, gas concentration can build up or become depleted below the measurement height. Gusts of wind can move this buildup sideways or upward very quickly, so this flux may be either undetected or only partially detected (Burba, 2013). Calm periods, coded in yellow color in Fig. 3, made up large portions in the monthly wind roses for April, May, Jun, July and September of 2010 (39\%, $38 \%, 47 \%, 48 \%$ and $34 \%$ respectively). EC data measured during "calm" months of the growing season should be carefully processed as it is this period of time that most contribution of forest ecosystem as a sink of $\mathrm{CO}_{2}$ takes place.

Higher wind speeds increase turbulence and decrease stability of atmospheric surface layer, which is better for eddy-covariance flux measurement method. However, under very strong wind conditions, signal brought to gas analyzer(s) may come from too close to the station. Flux data at very unstable conditions may need to be corrected or discarded due to the fact that a large portion of the flux may come from the disturbed area around the instrument tower (Burba, 2013).

\section{Conclusions}

In this study we assessed characteristics of wind patterns and calm conditions in Bílý Křriž Ecosystem Research Station. Key conclusions are:

+ Prevailing winds at Bílý Kř́ž site were mainly from $S$ and SW, (including strong winds of 6-8 and some records up to $12 \mathrm{~m} \mathrm{~s}^{-1}$ ) and to a much lesser extent from N, NE and NW but including the strongest winds greater than $12 \mathrm{~m} \mathrm{~s}^{-1}$.

+ On average of four years (2010-2013), calm periods took up $34 \%$ time of year.
+ Period from May to October (plant growing season) observed more calm records than period from November to April (39\% vs $28 \%$ respectively).

$+40 \%$ of night-time vs $39 \%$ of daytime were calm periods during May-October; and $30 \%$ vs $26 \%$ respectively during November-April.

\section{Acknowledgements}

This work was supported by the Ministry of Education, Youth and Sports of CR within the National Sustainability Program I (NPU I), grant number LO1415; and Project No. VAST.HTQT. Sec.01/16-17 of the Vietnam Academy of Science and Technology.

\section{References}

Barr, A., Richardson, A., Hollinger et al. 2013: Use of change-point detection for friction-velocity threshold evaluation in eddy-covariance studies. Agricultural and Forest Meteorology, 171-172: 31-45.

Burba, G. 2013: Eddy Covariance Method for Scientific, Industrial, Agricultural, and Regulatory Applications: A Field Book on Measuring Ecosystem Gas Exchange and Areal Emission Rates. LI-COR Biosciences, Lincoln, NE, USA, 331 pp.

Burba, G., Madsen, R., Feese, K. 2013: Eddy Covariance Method for $\mathrm{CO}_{2}$ Emission Measurements in CCUS Applications: Principles, Instrumentation and Software. Energy Procedia, 40C: 329-336.

Frauenfeld, O. W., Davis, R. E. 2003: Northern Hemisphere circumpolar vortex trends and climate change implications, J. Geophys. Res., 108, 4423, doi:10.1029/2002JD002958, D14.

Hájková, L., Voženílek, V., Tolasz, R., Kohut, M., MožnÝ, M., NeKovÁŘ́, J., NovÁK, M., Richterová, D., Stř́ǐz, M., VÁvra, A., Vondráková, A. 2012: Atlas of the phenological conditions in Czechia. Český Hydrometeorologický Ústav. Olomouc, Czech Republic, 320 pp.

Havránková, K., SedLĀK, P. 2004: Wind Velocity Analysis for Mountainous Site Bílý Kříž. Ekologia (Bratislava), 23: 46-54.

Marková,I.,Pavelka,M.,Janouš,D. 2013:Ročenka meteorologických mérení 2011. Yearbook of meteorological measurements in 2011. Brno: CzechGlobe, 125 pp. ISBN 978-80-87902-01-1. 
New World Encyclopedia 2015: Season. [Online]. Accessible at: http://web.newworldencyclopedia.org/entry/Season. [Accessed: 2017, October 30].

Randall, D. A., 2015: An Introduction to the Global Circulation of the Atmosphere. Princeton University Press, 442 pp., ISBN-13: 978-0691148960.

Sedlák, P., Aubinet, M., Heinesch, B., Janouš, D., Pavelka, M., Potužníková, K., Yernaux, M., 2010: Night-time airflow in a forest canopy near a mountain crest. Agricultural and Forest Meteorology, 150(5): 736-744. 